\title{
Peran motivasi kerja dan kepuasan kerja terhadap kinerja guru taman kanak-kanak non-PNS Kabupaten Kulon Progo
}

\author{
Sakiman \\ Magister Psikologi, Program Pascasarjana, Universitas Ahmad Dahlan \\ sakiman456@gmail.com
}

\begin{abstract}
ABSTRAK
Penelitian ini bertujuan untuk mengetahui peran motivasi kerja, dan kepuasan kerja terhadap kinerja Guru Taman Kanak- kanak non-PNS di Kabupaten Kulon Progo Utara. Hipotesis yang diajukan dalam penelitian ini ialah ada peran motivasi kerja dan kepuasan kerja terhadap kinerja Guru Taman Kanak- kanak non-PNS Kabupaten Kulon Progo Utara. Subjek penelitian ini adalah Guru Taman Kanak- kanak non-PNS di Kabupaten Kulon Progo Utara. Sebagai sampel subjek penelitian ini di kecamatan Sentolo sebanyak 70 orang. Instrumen yang digunakan dalam penelitian ini antara lain skala motivasi kerja, skala kepuasan kerja, dan skala kinerja guru. Teknik analisis yang digunakan dalam penelitian ini adalah analisis regresi yang diolah dengan menggunakan SPSS 17,0 for windows. Berdasarkan hasil analisis dapat disimpulkan sumbangan efektif variable motivasi kerja terhadap kinerja guru sebesar 31,578\% sedangkan sumbangan variable kepuasan kerja terhadap kinerja guru sebesar 45,3474\%, yang berarti bahwa variable kepuasan kerja memiliki sumbangan efektif lebih besar dibandingkan variable motivasi kerja terhadap kinerja guru Taman kanak-kanak non-PNS di Kabupaten Kulon Progo Utara.
\end{abstract}

Kata Kunci : Kinerja, Motivasi Kerja, Kepuasan Kerja

\begin{abstract}
This study aims to determine the role of work motivation, and job satisfaction on the performance of nonPNS Kindergarten Teachers in Kulon Progo Tuti Utara District. The hypothesis proposed in this study is that there is a role for work motivation and job satisfaction on the performance of Teachers of Non-PNS Kindergarten in North Kulon Progo Regency, The subjects of this study were non-PNS Kindergarten Teachers in Kulon Progo Tuti Utara District. As a sample the subject of this study in Sentolo sub-district was 70 people. The instruments used in this study include work motivation scale, job satisfaction scale, and teacher performance scale. The analysis technique used in this study is regression analysis which is processed using SPSS 17.0 for windows, Based on the results of the analysis it can be concluded that the effective contribution of work motivation variables on teacher performance is $31.578 \%$ while the variable contribution to job satisfaction on teacher performance is $45.3474 \%$, which means that the variable job satisfaction has an effective contribution greater than the work motivation variable on the teacher's school performance non-PNS children in North Kulon Progo Regency.
\end{abstract}

Keyword : Performance, Work Motivation, Workload

\section{PENDAHULUAN}

Kinerja merupakan salah satu bagian penting dalam organisasi, agar tujuan organisasi dapat dicapai dengan optimal. Untuk menyelesaikan tugas atau pekerjaan seseorang diperlukan kemauan dan kemampuan tertentu. Standar kinerja guru pada hakekatnya adalah suatu bentuk ukuran atau patokan yang dapat 
Jurnal Psikologi Terapan dan Pendidikan

ISSN: $2715-2456$

Vol. 1, No. 1, Mei 2019, pp. 30-44

menunjukkan jumlah dan mutu kerja yang diharapkan dapat dihasilkan guru dalam upaya memenuhi kebutuhan siswa. Fenomena yang terjadi saat ini adalah kinerja guru yang belum dapat sepenuhnya dijadikan sebagai ukuran/patokan baik oleh masyarakat sekolah maupun guru itu sendiri dalam memberikan pelayanan belajar pada siswa. Hal ini berkaitan dengan semakin derasnya tuntutan pelayanan pekerjaan yang profesional. Undang-undang Nomor 20 tahun 2003 tentang sistem pendidikan nasional, menunjukkan bahwa semakin kuatlah alasan pemerintah dalam melibatkan masyarakat dan pemerintah daerah dalam pengelolaan lembaga pendidikan pada jenjang pendidikan dasar dan menengah. Keterlibatan masyarakat dan pemerintah daerah tersebut mencakup beberapa aspek dari perencanaan, pelaksanaan, pengawasan, dan evaluasi program pendidikan (UU No. 20 Th. 2003, pasal 8), termasuk berkewajiban memberikan dukungan sumber daya dalam penyelenggaraan pendidikan.

Undang-undang Nomor 43 Tahun 1999 tentang perubahan atas Undang-undang Nomor 8 Tahun 1974, pasal 2 ayat (3) secara tegas dinyatakan, bahwa disamping Pegawai Negeri sebagaimana dimaksud dalam ayat (1) pejabat yang berwenang dapat mengangkat Pegawai Honorer. Dalam penjelasannya yang dimaksud dengan Pegawai Honorer jangka waktu tertentu guna melaksanakan tugas pemerintahan dan pembangunan yang bersifat teknis profesional dan administrasi sesuai dengan kebutuhan dan kemampuan organisasi dalam kerangka sistem kepegawaian.

Guru Non-PNS yang bekerja di lingkungan Departemen Pendidikan Nasional, ditempatkan di sekolah-sekolah baik negeri maupun swasta tergolong masih kurang. Sesuai hasil observasi di lapangan bahwa di kabupaten Kulon Progo bagian dari kota pendidikan di Daerah Istimewa Yogyakarta, masih terdapat guru Non-PNS yang tergolong tinggi. Permasalahan yang ada pada guru Non-PNS PAUD di Kabupaten Kulon Progo adalah kinerja guru rendah, penyebab rendahnya kinerja dikarenakan 1) Penilaian kinerja guru Non-PNS yang tidak semua sekolah ada, seperti tidak tersedia catatan penilaian dari tiap-tiap semester atau dari tahun ke tahun sehingga tidak dapat diketahui apakah terjadi peningkatan atau terjadi penurunan terhadap hasil kinerja yang dilakukan oleh kepala sekolah, 2) Ketidakpuasan guru Non-PNS TK di Kabupaten Kulon Progo terhadap keadaan tempat kerja guru mengajar, karena adanya faktor finansial, pengawasan dan beban pekerjaan yang tidak sebanding dengan imbalannya, 3) Motivasi kerja seorang guru Non-PNS TK di Kabupaten Kulon Progo rendah karena apa yang diperolehnya tidak sesuai dengan apa yang dikerjakannya, seperti kebutuhan makan, minum, perumahan, dan sebagainya tidak tercukupi dengan menjadi guru Non-PNS, 4) Guru Non-PNS TK masih belum merasa aman dengan kebutuhan akan kebebasan dari ancaman yaitu merasa aman dari ancaman kecelakaan dan keselamatan dalam melaksanakan pekerjaan. Karena guru Non-PNS membutuhkan kebutuhan sosial, teman, afiliasi, interaksi, dicintai dan mencintai, serta diterima dalam pergaulan kelompok pekerja dan masyarakat lingkungannya, 
Jurnal Psikologi Terapan dan Pendidikan

ISSN: $2715-2456$

Vol. 1, No. 1, Mei 2019, pp. 30-44

guru honorer juga mempunyai kebutuhan akan penghargaan dirinya serta mengaktualisasikan dirinya, 5)

Faktor status yang melekat pada guru Non-PNS otomatis gaji yang diterima selama ini jauh dari cukup, sehingga mengakibatkan rendahnya kinerja guru Non-PNS TK.

Kinerja guru sebagai hasil kerja dari seorang guru dalam menjalankan tugas pokoknya sebagai pendidik meliputi merencanakan pembelajaran, melaksanakan pembelajaran, menilai hasil pembelajaran, membimbing dan melatih peserta didik, serta melaksanakan tugas tambahan yang melekat pada pelaksanaan tugas pokok (Puspitasari, 2011). Sedangkan Pujiyanti dan Iroah (2013) memberikan pengertian kinerja guru sebagai hasil kerja yang telah dicapai oleh seorang guru dalam menjalankan tugasnya sesuai dengan tanggung jawab dan tugas yang diberikan, yaitu menyelenggarakan pembelajaran sesuai dengan prinsip-prinsip profesionalitas serta mencapai tujuan pendidikan nasional.

Dengan demikian perihal tenaga pengajar atau guru dengan kinerjanya adalah menyangkut seluruh aktivitas yang ditunjukkan oleh guru dalam tanggung jawabnya sebagai orang yang mengemban suatu amanat dan tanggung jawab untuk mendidik, mengajar, membimbing, mengarahkan, dan memandu peserta didik dalam rangka membantu perkembangan peserta didik ke arah kedewasaan mental spiritual maupun fisik biologis. Jadi kinerja guru adalah perilaku atau respon yang memberi hasil yang mengacu kepada apa yang mereka kerjakan ketika dia menghadapi suatu tugas (Yamin \& Maisah, 2010).

Konsep kinerja merupakan singkatan dari kinetika energi kerja yang sama dalam bahasa Inggris adalah performance. Istilah performance sering diindonesiakan sebagai performa. Kinerja adalah keluaran yang dihasilkan oleh fungsi-fungsi atau indikator-indikator suatu pekerjaan atau suatu profesi dalam waktu tertentu (Wirawan, 2009). Kinerja guru adalah konsep yang menunjukkan adanya kaitan out-put dengan input yang dibutuhkan seorang tenaga kerja untuk menghasilkan produk (Robert \& John, 2006). Pengukuran kinerja dilakukan dengan melihat jumlah output yang dihasilkan oleh setiap karyawan. Seorang karyawan dapat dikatakan baik apabila ia mampu menghasilkan jumlah produk yang lebih banyak dibandingkan dengan pegawai lain dalam waktu yang sama. Jadi produktivitas terlihat melalui beberapa jumlah produk yang dihasilkan oleh karyawan dalam waktu tertentu.

Penilaian kinerja guru tidak hanya menilai hasil fisik tetapi pelaksanaan pekerjaan secara keseluruhan yang menyangkut berbagai bidang seperti kemampuan kerja, kerajinan, disiplin, hubungan kerja atau hal-hal khusus sesuai dengan bidang dan level yang dijabatnya yaitu (Wirawan, 2009). Indikator kinerja guru yang diadopsi dari (Wakir, 2012) terdiri dari a) Perencanaan, pelaksanaan dan evaluasi pembelajaran dalam konteks ini pembelajaran dapat diartikan sebagai suatu proses penyusunan materi pembelajaran, penggunaan media pengajaran, penggunaan atau pendekatan metode, dan penilaian, menentukan alokasi waktu untuk mencapai tujuan tertentu. Berdasarkan uraian di atas, konsep perencanaan, 
Jurnal Psikologi Terapan dan Pendidikan

ISSN: $2715-2456$

Vol. 1, No. 1, Mei 2019, pp. 30-44

pelaksanaan dan evaluasi pembelajaran dapat dilihat dari berbagai sudut pandang sebagai berikut (Wirawan, 2009), b) Perencanaan pembelajaran sebagai sebuah proses adalah pengembangan pembelajaran secara sistematik yang menggunakan secara khusus teori-teori pembelajaran untuk menjamin berlangsungnya kualitas pembelajaran. Perencanaan pembelajaran ini akan menganalisis tentang kebutuhan dari proses belajar secara sistemik yang dimulai dari proses perancangan, pelaksanaan dan evaluasi hasil belajar, c) Perencanaan pembelajaran sebagai sebuah disiplin adalah cabang dari pengetahuan yang senantiasa memperhatikan hasil-hasil penelitian dan teori-teori tentang strategi pembelajaran dan implementasinya dalam kegiatan mengajar, d) Perencanaan pembelajaran sebagai sebuah sains adalah mengkreasi secara detail spesifikasi dari pengembangan implementasi, evaluasi, pemeliharaan akan situasi maupun fasilitas pembelajaran, e) Perencanaan pembelajaran sebagai sebuah realitas adalah ide pengajaran yang dikembangkan dengan melakukan pengecekan dan perbaikan dari waktu ke waktu untuk memperbaiki kualitas pembelajaran, f) Perencanaan pembelajaran sebagai suatu sistem yang terdiri dari gabungan berbagai subsistem yakni terkait dengan tujuan, materi, metode/strategi, media, evaluasi, fasilitas, potensi akademik siswa dan sumber/referensi, g) Perencanaan pembelajaran sebagai sebuah teknologi adalah suatu perencanaan yang mendorong penggunaan teknik yang dapat mengembangkan kemampuan kognitif dan teori-teori konstruktif terhadap solusi dari problem pengajaran. h) Kerja sama dalam kelompok kerja seperti kuantitas guru, aktivitas guru, kelompok guru, hubungan-hubungan antar guru, faktor pengikat para guru, kepentingan-kepentingan, saling ketergantungan, dan ukuran-ukuran perilaku atau norma-norma yang sama-sama dipatuhi oleh guru. Faktor-faktor tersebut merupakan indikator keberhasilan guru akan bekerjasama dengan kelompok kerja yang dibentuk guru itu sendiri (Armstong, 2004), i) Pemahaman dan kemampuan mengajar adalah kemampuan esensial yang harus dimiliki oleh guru, tidak lain karena tugas yang paling utama adalah mengajar. Dalam proses pembelajaran, guru menghadapi siswa-siswa yang dinamis, baik sebagai akibat dari dinamika internal yang berasal dari dalam diri siswa maupun sebagai akibat tuntutan dinamika lingkungan yang sedikit banyak berpengaruh terhadap siswa. Oleh karena itu, kemampuan mengajar harus dinamis juga sebagai tuntutan-tuntutan siswa yang tak terelakkan. Kemampuan mengajar guru sebenarnya merupakan pencerminan guru atas kompetensinya (Mulyasa, 2006).

Menurut Sudjana (2002), terdapat empat kompetensi yang harus dimiliki guru, antara lain a) Mempunyai pengetahuan tentang belajar tingkah laku manusia. b) Mempunyai pengetahuan dan menguasai bidang studi yang dibinanya. c) Mempunyai sikap yang tepat tentang dirinya, sekolah, teman sejawat dan bidang studi yang dibinanya. d) Mempunyai kemampuan tentang teknik mengajar antara lain : i) Evaluasi diri akan prestasi kerja adalah suatu metode dan proses penilaian dan pelaksanaan tugas seseorang guru atau sekelompok guru atau unit-unit kerja dalam satu sekolah sesuai dengan standar kinerja atau tujuan 
Jurnal Psikologi Terapan dan Pendidikan

ISSN: $2715-2456$

Vol. 1, No. 1, Mei 2019, pp. 30-44

yang ditetapkan lebih dahulu. Evaluasi diri akan prestasi kerja merupakan cara yang paling adil dalam memberikan imbalan atau penghargaan kepada guru. Tujuan evaluasi diri akan prestasi kerja adalah untuk menjamin pencapaian sasaran dan tujuan pendidikan di sekolah dan juga untuk mengetahui posisi sekolah dan tingkat pencapaian sasaran sekolah, terutama untuk mengetahui bila terjadi keterlambatan atau penyimpangan supaya segera diperbaiki, sehingga sasaran atau tujuan tercapai. Hasil evaluasi diri akan prestasi kerja guru dapat dimanfaatkan untuk banyak penggunaan.

Umar (2003), membagi aspek-aspek kinerja sebagai berikut a) Mutu pekerjaan (kualitas kerja), Sebuah proses yang merespon pada kebutuhan pegawai dengan mengembangkan suatu mekanisme yang memberikan kesempatan secara penuh kepada pegawai dan merencanakan kehidupan kerja mereka, b) Inisiatif Suatu gagasan atau ide-ide pokok, metode dan pendekatan baru mengenai suatu hal yang perlu adanya pembaharuan dan perkembangan, c) Kerja sama karyawan merupakan kontributor sejajar dalam proses manajemen kinerja, karena karyawan harus menjadi peserta aktif dan antusias dalam menjalankan setiap proses kerja sesuai dengan ketentuan yang telah diinformasikan, sehingga keterlibatannya akan membangun rasa memiliki dan tanggung jawab, d) Pengetahuan tentang pekerjaan, Melalui informasi mengenai suatu pekerjaan yaitu melalui analisis jabatan akan diketahui apakah seseorang merasakan pekerjaannya terlalu sederhana atau terlalu rumit, e) Tanggung jawab, dapat diartikan dengan hasil yang harus dicapai atau tindakan yang harus dilakukan untuk mencapai tujuan dari suatu kegiatan atau program, f) Komunikasi dan berinteraksi merupakan bagian terpenting dalam kehidupan kerja. Hal ini mudah dipahami sebab komunikasi yang tidak baik bisa mempunyai dampak yang luas terhadap kehidupan organisasi.

Faktor-faktor yang mempengaruhi kinerja pegawai adalah faktor individu, organisasi, dan factor psikologis antara lain a) Faktor individu, meliputi kemampuan, keterampilan mental dan fisik, latar belakang keluarga, tingkat sosial, pengalaman serta demografi yang mencakup, umur, asal-usul, dan jenis kelamin, b) Faktor organisasi, meliputi sumber daya, kepemimpinan, imbalan, dan struktur desain kerja, c) Faktor psikologis, meliputi persepsi, sikap, kepribadian, belajar serta motivasi .

Menurut pendapat Keith Davis (Anwar \& Mangkunegara, 2005) terdapat dua faktor yang mempengaruhi kinerja antara lain a) Faktor Kemampuan (Ability) secara psikologis, kemampuan terdiri dari kemampuan potensi (IQ) dan kemampuan reality (knowledge + skill) artinya bahwa pimpinan dan karyawan yang memiliki IQ diatas rata-rata (110-120) serta genius dan memiliki pendidikan yang memadai untuk melaksanakan jabatannya dan terampil dalam mengerjakan pekerjaan sehari-hari, maka akan lebih mudah untuk mencapai kinerja yang maksimal, b) Faktor Motivasi (motivation) merupakan suatu sikap (attitude) pemimpin dan karyawan terhadap situasi kerja di lingkungan organisasinya. Anthony dan 
Jurnal Psikologi Terapan dan Pendidikan

ISSN: 2715-2456

Vol. 1, No. 1, Mei 2019, pp. 30-44

Govindarajan (2001) mengatakan bahwa tujuan sistem pengukuran kinerja adalah untuk melaksanakan strategi. Dalam menetapkan sistem manajemen tersebut, manajemen senior memilih ukuran-ukuran yang paling tepat mencerminkan strategi. Untuk bisa melaksanakannya dengan berhasil, sistem pengukuran kinerja harus menempuh empat langkah: (1) mendefinisikan strategi, (2) mendefinisikan ukuran strategi, (3) mengintegrasikan ukuran-ukuran itu ke dalam sistem manajemen, dan (4) meninjau ukuran-ukuran dan hasil-hasilnya (Anthony \& Govindarajan, 2001).

Pamela dan Oloko (2015) Motivasi adalah kunci dari organisasi yang sukses untuk menjaga kelangsungan pekerjaan dalam organisasi dengan cara dan bantuan yang kuat untuk bertahan hidup. Motivasi adalah memberikan bimbingan yang tepat atau arahan, sumber daya dan imbalan agar mereka terinspirasi dan tertarik untuk bekerja dengan cara yang anda inginkan. Chukwuma dan Obiefuna (2014) Motivasi adalah proses membangkitkan perilaku, mempertahankan kemajuan perilaku, dan menyalurkan perilaku tindakan yang spesifik. Dengan demikian, motif (kebutuhan, keinginan) mendorong karyawan untuk bertindak.

Motivasi dikatakan sebagai kebutuhan yang mendorong perbuatan ke arah suatu tujuan tertentu Motivasi kerja adalah suatu yang menimbulkan semangat atau dorongan kerja. Oleh sebab itu, motivasi kerja dalam psikologi biasa disebut pendorong semangat kerja. Kuat dan lemahnya motivasi kerja seorang tenaga kerja ikut menentukan besar kecilnya prestasinya. (Anoraga, 2009). Motivasi adalah salah satu faktor paling penting yang mempengaruhi perilaku manusia dan kinerja. Teori Motivasi telah dibahas dan dikonsep oleh berbagai peneliti. Tingkat motivasi seorang individu atau tim diberikan dalam tugas atau pekerjaan mereka yang dapat mempengaruhi semua aspek kinerja organisasi. Dalam penelitian terbaru, motivasi didefinisikan oleh Saraswathi (2011) sebagai kesediaan untuk mengerahkan tingkat tinggi usaha, menuju tujuan organisasi, yang dikondisikan oleh kemampuan upaya untuk memenuhi beberapa kebutuhan individual. Wan dan Tan (2013) mendifinisikan motivasi adalah suatu proses yang membangkitkan, mengarahkan dan menjaga atau memelihara perilaku manusia agar terarah pada tujuan. Menurut Robbins (Hasibuan, 2005) motivasi sebagai suatu kerelaan untuk berusaha seoptimal mungkin dalam pencapaian tujuan organisasi yang dipengaruhi oleh kemampuan usaha untuk memuaskan beberapa kebutuhan individu.

Berdasarkan beberapa pendapat yang dikemukakan oleh para ahli dapat disimpulkan bahwa motivasi kerja adalah suatu proses dimana kebutuhan mendorong seseorang untuk melakukan serangkaian kegiatan yang mengarah ke tercapainya tujuan tertentu dan tujuan organisasi dan untuk memenuhi beberapa kebutuhan. Kuat lemahnya motivasi kerja seorang tenaga kerja ikut menentukan besar kecilnya prestasi kinerja. 
Jurnal Psikologi Terapan dan Pendidikan

ISSN: 2715-2456

Vol. 1, No. 1, Mei 2019, pp. 30-44

Munandar (2001) mengemukakan aspek motivasi kerja antara lain a) adanya kedisiplinan dari karyawan yaitu, sikap tingkah laku atau perbuatan pada karyawan untuk melakukan aktivitas-aktivitas kerja yang sesuai dengan pola-pola tertentu. Keputusan-keputusan dan norma-norma yang telah ditetapkan dan disetujui bersama baik tulis maupun lisan serta sanggup menerima sanksi bila melanggar tugas dan wewenang yang diberikan, b) Imajinasi yang tinggi dan daya kombinasi yaitu membuat hasil kerja dan kombinasi ide-ide atau gambaran disusun secara lebih teliti atau inisiatif sendiri bukan ditiru dan bersifat konstruktif sehingga membentuk suatu hasil atau produk yang mendukung pada kualitas kerja yang lebih baik, c) Kepercayaan diri yaitu perasaan yakin yang dimiliki karyawan terhadap kemampuan dirinya. Daya berfikir positif dalam menghadapi kenyataan yang terjadi serta bertanggung jawab atas keputusan yang dapat diambil sehingga dapat menyelesaikan masalahnya dengan tenang, d) Daya tahan terhadap tekanan merupakan reaksi karyawan terhadap pengalaman emosional yang tidak menyenangkan yang dirasakan sebagai ancaman atau sebab adanya ketidakseimbangan antara tuntutan dan kemauan yang dimilik, dan tekanan tersebut diselesaikan dengan cara tersendiri yang khas bagi masing-masing individu , e) Tanggung jawab dalam melakukan pekerjaan merupakan suatu kesadaran pada individu untuk melaksanakan kewajiban atau pekerjaan, diiringi rasa keberanian menerima segala resiko, inisiatif yang besar dalam menghadapi kesulitan terhadap pekerjaan dan dorongan yang besar untuk menyelesaikan apa yang harus dan patut diselesaikan.

Menurut George dan Jones (Ella, 2015) mengemukakan 3 aspek motivasi kerja antara lain adalah a) Perilaku (direction of behavior), b) Tingkat Usaha (Level of effort), c) Tingkat Kegigihan (level of persistence). Winardi (2001) menggungkapkan terdapat tiga aspek motivasi yang mengarah tercapainya tujuan tertentu, yaitu a) Keinginan, ketika seseorang memiliki keinginan maka motivasinya terpacu untuk melakukan suatu pekerjaan agar tercapai sesuai yang diinginkannya. b) Kebutuhan, seseorang memiliki motivasi yang tinggi bila seseorang butuh. Ketika seseorang membutuhkan sesuatu misalnya gaji, kompensasi maka pekerjaan akan terpacu untuk melakukan pekerjaannya dengan baik, c) Rasa aman, seseorang akan berusaha melakukan sesuatu juga disebabkan ketakutan saat orang tersebut tidak melakukan sesuatu sehingga alas an motivasi muncul karena ketika seseorang melakukan sesuatu dirinya merasa aman.

Berdasarkan beberapa pendapat yang dikemukakan oleh para ahli dapat disimpulkan bahwa aspekaspek dari motivasi kerja adalah : adanya kedisiplinan karyawan, imajinasi yang tinggi dan daya kombinasi, kepercayaan diri, daya tahan terhadap tekanan, tanggung jawab dalam melakukan pekerjaan, perilaku (direction of behavior), tingkat usaha (level of effort), tingkat kegigihan (level of persistence), keinginan, kebutuhan, rasa aman. 
Jurnal Psikologi Terapan dan Pendidikan

ISSN: $2715-2456$

Vol. 1, No. 1, Mei 2019, pp. 30-44

Kepuasan kerja dapat diartikan sebagai besarnya rasa suka karyawan terhadap pekerjaannya dan ketidakpuasan kerja menunjukkan besarnya rasa tidak suka karyawan terhadap pekerjaan. Kepuasan kerja mencerminkan sikap tenaga kerja terhadap pekerjaannya. Robbins dan Coulter (Khalid, dkk 2013) Ini mengacu pada pendapat umum karyawan terhadap/pekerjaannya, seperti orang dengan tingkat tinggi kepuasan kerja memiliki perasaan positif terhadap pekerjaannya, sedangkan orang yang tidak bahagia dengan pekerjaan dapat mencengkeram sikap negative. Menurut Wexley dan Yukl (As'ad, 2002) yang disebut kepuasan kerja ialah perasaan seseorang terhadap pekerjaanya. Menurut Wexley dan Yukl (As'ad, 2002) kepuasan dan tidak kepuasan terhadap pekerjaan itu tidak merupakan suatu variable yang kontinyu.

Setiap individu akan memiliki tingkat kepuasan yang berbeda-beda sesuai dengan system nilainilai yang berlaku pada dirinya. Hal ini disebabkan karena adanya perbedaan pada masing-masing individu. Semakin banyak aspek-aspek dalam pekerjaan yang sesuai dengan keinginan individu tersebut, maka semakin tinggi tingkat kepuasan yang dirasakannya (Anoraga, 2009).

Berdasarkan beberapa pendapat para ahli maka dapat disimpulkan kepuasan kerja adalah suatu sikap berupa refleksi dari perasaan karyawan terhadap keseluruhan pekerjaan. Kepuasan kerja dapat diartikan sebagai besarnya rasa suka karyawan terhadap pekerjaannya, pegawai yang merasa senang dan puas dengan pekerjaannya tentu ia akan melaksanakan tugasnya dengan sebaik-baiknya sehingga akan berdampak positif terhadap hasil kerjanya.

Aspek-aspek kepuasan kerja yang diungkap oleh Blum (Yulihastuti, 2003) yaitu a) Pekerjaan itu sendiri yaitu termasuk tugas yang diberikan, ekspresi kerja serta hal lain yang berhubungan dengan pekerjaan, kondisi, dan lingkungan kerja, sikap kerja yang ditangani, minat untuk menekuni dan konsentrasi pada pekerjaan, b) Promosi merupakan kenaikan pangkat maupun jabatan, kesempatan untuk maju, pengembangan karir dan prospek masa depan, prestasi yang merupakan usaha subyek untuk mencapai hasil yang lebih baik dengan kondisi yang ada pada dirinya, c) Gaji dan jaminan social adalah gaji bersih yang diterima setiap bulan dan jaminan sosial lainnya, d) Teman sekerja meliputi hubungan antara pegawai, harapan keluarga dan pandangan masyarakat, e) Pengawasan atau supervise yaitu hubungan antar pegawai dan atasan, peraturan kerja dan kualitas kerja.

Anoraga (2009) menyatakan aspek-aspek yang dapat mempengaruhi kepuasan kerja adalah a) Rasa aman, yaitu adanya kepastian pegawai untuk memperoleh pekerjaan tetap, memangku jabatan di organisasi selama mungkin seperti yang diharapkan, b) Kesempatan untuk maju dan berkembang yaitu adanya kemungkinan bagi pegawai untuk maju, naik pangkat, kedudukan dan keahlian atau pengalaman, c) Gaji atau uang, yaitu Instansi yang memberikan kebanggaan kepada karyawan apabila mereka bekerja di Instansi yang bersangkutan, d) Nama baik tempat kerja, yaitu organisasi yang memberikan kebanggaan kepada 
Jurnal Psikologi Terapan dan Pendidikan

ISSN: $2715-2456$

Vol. 1, No. 1, Mei 2019, pp. 30-44

pegawai apabila mereka bekerja diorganisasi yang bersangkutan, e) Kesempatan berprestasi, yaitu organisasi yang memberikan kesempatan untuk dapat mengembangkan potensi yang ada dalam dirinya sehingga mencapai tingkat kerja yang maksimal.

Berdasarkan atas beberapa pendapat yang dikemukakan para ahli disimpulkan bahwa aspek-aspek kepuasan kerja meliputi pekerjaan itu sendiri, promosi, gaji dan jaminan sosial, teman sekerja dan pengawasan atau supervise, rasa aman, kesempatan untuk maju dan berkembang, gaji atau uang, nama baik tempat kerja dan kesempatan berprestasi serta pengakuan diri, financial dan jaminan sosial, kondisi dan lingkungan fisik kerja, kesempatan untuk maju dan berkembang, dan psikologis.

Penelitian ini bertujuan untuk 1) Mengetahui seberapa besar peran Kepuasan kerja dan motivasi kerja secara bersama-sama terhadap kinerja guru taman kanak-kanak non-PNS di Kabupaten Kulon Progo Utara, 2) Mengetahui peran Kepuasan kerja terhadap kinerja guru-guru taman kanak-kanak non-PNS di Kabupaten Kulon Progo Utara, 3) Mengetahui peran Motivasi kerja terhadap kinerja guru guru taman kanak-kanak non-PNS di kabupaten Kulon Progo Utara.

\section{METODE PENELITIAN}

Penelitian ini merupakan penelitian kuantitatif yang secara garis besar memiliki tiga variabel yaitu kinerja sebagai variabel terikat, motivasi dan kepuasan kerja sebagai variabel bebas. Populasi dalam penelitian ini adalah semua Guru PAUD Non-PNS tingkat Taman Kanak-kanak yang tersebar di berbagai wilayah Kabupaten Kulon Progo Utara yang berjumlah 5 kecamatan sekitar 174 orang. Skala yang digunakan dalam penelitian ini adalah skala motivasi kerja, skala kepuasan kerja dan skala kinerja. Teknik yang digunakan untuk menganalisa data pada penelitian ini ialah teknik analis regresi dengan bantuan komputerisasi SPSS (Statistical Product and Service Solutions) 16 for Windows, yang bertujuan untuk melihat seberapa besar sumbangan efektif motivasi kerja dan kepuasan kerja dengan kriterium yaitu kinerja.

Uji normalitas bertujuan untuk menguji apakah dalam model regresi, variabel penganggu atau residual memiliki distribusi normal. Secara kasat mata normalitas residual dapat dilihat melalui grafik histogram yang membandingkan antara dua observasi dengan distribusi yang mendekati normal. Secara empiris normalitas residual dapat menganalisa secara statistik dengan uji Kolmogorov-Smirnov (K-S). Asumsi normalitas residual terpenuhi apabila nilai signifikan K-S > 0,05 pengujian ini dilakukan dengan menggunakan program SPSS 17 for windows. Uji linieritas bertujuan untuk mengetahui sifat hubungan antara variabel bebas variabel tergantung. Pengujian linieritas dimaksud untuk mengetahui perbedaan variabel bebas memprediksi variabel tergantung. Uji linieritas dilakukan dengan menggunakan test of 
Jurnal Psikologi Terapan dan Pendidikan

ISSN: 2715-2456

Vol. 1, No. 1, Mei 2019, pp. 30-44

linearity dan indeks penyimpangan linieritas ( $F$ deviation form linierity). Linier tidaknya variabel penelitian dapat dilihat dari F hitung atau nilai signifikansi ( $\mathrm{p}>0,05)$.

\section{HASIL}

Disimpulkan bahwa motivasi kerja terhadap kinerja guru mempunyai F hitung sebesar 286,385 dan nilai signifikansi sebesar 0,000 yang artinya nilai signifikansi $(\mathrm{p})>0,05$ dengan demikian ada hubungan linier antara motivasi kerja dengan kinerja guru. Pada variabel kepuasan kerja terhadap kinerja guru mempunyai $\mathrm{F}$ hitung sebesar 208,226 dengan nilai signifikan sebesar 0,03 yang artinya nilai signifikan (p) > 0,05 dengan demikian ada hubungan linier antara kepuasan kerja dengan kinerja guru, sehingga bisa disimpulkan bahwa hubungan semua variabel bebas terhadap variabel terikat adalah linier.

Uji multikolinieritas dilakukan menggunakan teknik regresi dan dilakukan dengan melihat nilai Tolerance dan varians inflation factor (VIF). Hasil uji multikolinieritas menunjukkan bahwa variabel motivasi kerja sebesar VIF=3,575. Hasil uji variabel kepuasan kerja VIF=3,575. Artinya semua variabel dinyatakan tidak terjadi multikolinieritas dengan kriteria nilai Tolerance $>0,10$ dan VIF $<10$. Uji hipotesis dilakukan untuk mengetahui peran variabel bebas (Motivasi kerja dan Kepuasan kerja) terhadap variabel terikat (Kinerja guru). Untuk menguji hipotesis mayor digunakan analisis regresi. Berdasarkan hasil analisis data diketahui bahwa besarnya koefisien korelasi antara variabel Motivasi kerja dan kepuasan kerja dengan kinerja guru diperoleh skor $\mathrm{R}=0,877$ dengan nilai $\mathrm{p}=0,000(\mathrm{p}<0,01)$ sehingga hipotesis mayor dapat diterima.

Berdasarkan hasil analisis R square sebesar 0,769 dipresentasikan $(0,769 \times 100 \%=76,9 \%)$ artinya besar sumbangan motivasi kerja dan kepuasan kerja sebesar 76,9\%, sedangkan sisanya 23,1\% dipengaruhi faktor lain yang tidak diteliti dalam penelitian ini. Dari hasil tabel diketahui df 2, nilai F sebesar 111,741 dengan $\mathrm{P}=0.000(\mathrm{P}<0,01)$. Berdasarkan hasil uji regresi berganda motivasi kerja dan kepuasan kerja sebesar 0,000 $(\mathrm{P}<0,01)$. Sehingga dapat disimpulkan motivasi kerja dan kepuasan kerja berperan terhadap kinerja guru.

Hasil Motivasi kerja dan kinerja diperoleh dari analisis data diketahui bahwa besarnya koefisien korelasi $\beta$ adalah 0,380 antara variabel kinerja guru dengan motivasi kerja sedangkan nilai t 3,428 sehingga hipotesis minor pertama diterima. Hal ini menunjukkan bahwa terdapat peran yang signifikan antara variabel Motivasi kerja dan kinerja guru $(\mathrm{P}<0,001)$. Sedangkan hasil kepuasan kerja dengan kinerja guru dapat dilihat dari koefisien $\beta 0,531$ dan nilai t sebesar 4,786. Hal ini menunjukkan ada peran yang sangat signifikan antara kepuasan kerja dan kinerja guru $(\mathrm{P}<0,01)$.

Berdasarkan pemaparan di atas hipotesis minor yang diajukan teruji kebenarannya, hal ini menunjukkan ada peran yang sangat signifikan antara motivasi kerja dan kepuasan kerja dengan kinerja 
Jurnal Psikologi Terapan dan Pendidikan

ISSN: $2715-2456$

Vol. 1, No. 1, Mei 2019, pp. 30-44

guru, yang berarti semakin tinggi motivasi kerja dan kepuasan kerja akan semakin tinggi pula kinerja guru Non-PNS begitu pula sebaliknya, semakin rendah motivasi kerja dan kepuasan kerja maka rendah pula kinerja guru Non-PNS.

Sumbangan efektif variabel motivasi kerja terhadap kinerja gurusebesar $31,578 \%$ sedangkan sumbangan efektif variabel kepuasan kerja terhadap kinerja guru sebesar 45,3474\%. Berdasarkan hasil analisis sumbangan efektif variabel motivasi kerja terhadap kinerka guru sebesar $31,578 \%$. Sedangkan sumbangan pada variabel kepuasan kerja terhadap kinerja guru sebesar 45,3474\%. Yang berarti bahwa variabel kepuasan kerja memiliki sumbangan efektif lebih besar dibandingkan variabel motivasi kerja terhadap kinarja guru. Berdasarkan hasil analisis uji multikolinieritas diperoleh hasil bahwa antara variabel bebas tidak terjadi multikolinieritas sehingga memenuhi syarat untuk di analisis regresi.

\section{PEMBAHASAN}

Peran Motivasi kerja terhadap kinerja guru menunjukkan bahwa terdapat peran positif antara motivasi terhadap kinerja guru Taman Kanak-kanak di Kabupaten Kulon Progo Utara. Peran positif menunjukkan bahwa semakin tinggi motivasi kerja, maka kinerja guru akan meningkat. Semakin terpenuhi kebutuhan guru seperti kebutuhan mempertahankan hidup, kebutuhan akan rasa aman, kebutuhan sosial, kebutuhan akan penghargaan, kebutuhan prestasi,kebutuhan dalam mengaktualisasikan diri di sekolah, maka guru akan berusaha meningkatkan kinerjanya. Skor tertinggi asfek variable motivasi kerja terdapat pada asfek kebutuhan sosial, maka pemenuhan kebutuhan sosial yang akan mendorong mereka untuk meningkatkan kinerjanya karena posisi guru dianggap memiliki status social tinggi di masyarakat.

Berdasarkan hasil penelitian diketahui bahwa motivasi kerja guru Taman Kanak-kanak Non-PNS di Kabupaten Kulon Progo Utara sudah cukup tinggi, namun masih perlu ditingkatkan, yaitu kebutuhan mempertahankan hidup, kebutuhan akan rasa aman, kebutuhan sosial, kebutuhan akan penghargaan, kebutuhan prestasi, kebutuhan dalam mengaktualisasikan diri di sekolah.

Peran Kepuasan Kerja terhadap Kinerja Guru menunjukkan bahwa terdapat peran positif antara kepuasan kerja terhadap kinerja guru Taman Kanak-kanak Non-PNS di Kabupaten Kulon Progo Utara. Peran positif menunjukkan bahwa semakin puas guru Non-PNS akan pekerjaannya, maka kinerja guru akan meningkat. Peran kepuasan terhadap gaji yang diperolehanya, perkembangan karier yang didapatkan, hubungan yang harmonis antar rekan kerja dan pengawasan kepala sekolah yang ideal, akan menjadi guru honorer berusaha untuk meningkat kinerjanya. Skor tertinggi asfek variabel kepuasan kerja terdapat pada asfek rekan kerja, Hubungan rekan kerja yaitu hubungan guru dengan guru atau pun dengan kepala sekolah 
Jurnal Psikologi Terapan dan Pendidikan

ISSN: $2715-2456$

Vol. 1, No. 1, Mei 2019, pp. 30-44

merupakan salah satu sikap yang sulit digambarkan tetapi dipandang sebagai faktor yang menunjang puas atau tidak puas dalam kerja guru (Ass'ad, 2003).

Peran Kepuasan kerja dan Motivasi Kerja terhadap Kinerja Guru menunjukkan bahwa terdapat pengaruh positif antara kepuasan kerja dan motivasi kerja terhadap kinerja guru di Taman Kanak-kanak Non-PNS di Kabupaten Kulon Progo Utara. Semakin tinggi kepuasan dan motivasi kerjanya, maka kinerja guru akan meningkat. Untuk meningkatkan kinerja guru, maka diperlukan peningkatan secara serentak antara kepuasan kerja dan motivasi kerja yaitu dengan meningkatkan sikap terhadap pekerjaan dalam bekerja, gaji, insentif dan bonus yang didapatkan, perkembangan karir guru honorer, dan hubungan dengan rekan kerja, serta hubungan dengan pimpinan atau atasan. Guru yang memiliki kepuasan terhadap gaji, karir dan hubungan rekan dan pimpinan akan memiliki motivasi pengakuan sosial yang tinggi, maka mereka akan berusaha memaksimalkan kerja mereka untuk mendapatkan hasil yang terbaik. Data yang diperoleh dari analisis data dapat ditarik kesimpulan hipotesis minor diterima. Hasil analisis juga menunjukkan ada hubungan yang sangat signifikan antara kepuasan kerja dan kinerja guru .

Berdasarkan pemaparan di atas hipotesis minor yang diajukan teruji kebenarannya, hal ini menunjukkan ada hubungan yang sangat signifikan antara motivasi kerja dan kepuasan kerja terhadap kinerja guru, yang berarti semakin tinggi motivasi kerja dan kepuasan kerja akan semakin tinggi pula kinerja guru Non-PNS begitu pula sebaliknya, semakin rendah motivasi kerja dan kepuasan kerja maka rendah pula kinerja guru Non-PNS.

Beberapa kekurangan yang ada dalam penelitian ini adalah sebagai berikut Jumlah item pertanyaan banyak yang gugur. Dalam penelitian ini ada 11 pertanyaan gugur dalam uji validitas, sehingga tidak semua asfek yang dijelaskan memprediksikan hasil penelitian, untuk peneliti selanjutnya supaya lebih menambah item pertanyaan lagi sehingga semua aspek dapat terwakili. Kekurangan selanjutnya adalah hanya menggunakan 2 variabel independent untuk memprediksi variabel dependent. Jumlah variabel yang diambil lebih banyak untuk peneliti selanjutnya dapat mengetahui lebih banyak faktor terkait faktor yang dapat berperan terhadap kinerja guru.

\section{KESIMPULAN}

Berdasarkan hasil penelitian yang telah dilakukan, maka dapat disimpulkan bahwa 1) Motivasi kerja memiliki peran positif dan signifikan terhadap kinerja guru Non-PNS Taman Kanak-kanak di Kabupaten Kulon Progo Utara. Dari hasil analisis regresi linier berganda dapat disimpulkan pula bahwa hipotesis kedua diterima. Semakin terpenuhi kebutuhan guru seperti kebutuhan mempertahankan hidup, kebutuhan akan rasa aman, kebutuhan sosial, kebutuhan akan penghargaan, kebutuhan prestasi, kebutuhan 
Jurnal Psikologi Terapan dan Pendidikan

ISSN: 2715-2456

Vol. 1, No. 1, Mei 2019, pp. 30-44

dalam mengaktualisasikan diri di sekolah, maka guru akan berusaha meningkatkan kinerjanya, 2) Kepuasan kerja memiliki peran positif dan signifikan terhadap kinerja guru Taman Kanak-kanak Non-PNS di Kabupaten Kulon Progo Utara. Hal ini dapat dibuktikan berdasarkan hasil analisis regresi linier berganda yang diperoleh dan disimpulkan bahwa hipotesis pertama diterima. Jadi, apabila kepuasan kerja guru NonPNS meningkat, maka kinerja guru akan meningkat pula. Semakin terpenuhi kebutuhan guru seperti kebutuhan mempertahankan hidup, kebutuhan akan rasa aman, kebutuhan sosial, kebutuhan akan penghargaan, kebutuhan prestasi, kebutuhan dalam mengaktualisasikan diri di sekolah, maka guru akan berusaha meningkatkan kinerjanya, 3) Motivasi kerja dan Kepuasan kerja memiliki peran positif dan signifikan terhadap kinerja guru Taman Kanak-kanak Non-PNS di Kabupaten Kulon Progo Utara.

Sehingga dapat disimpulkan pula hipotesis ketiga diterima. Apabila guru dalam melakukan pekerjaan memiliki kepuasan yang tinggi, maka hal ini akan memotivasi guru untuk melakukan pekerjaan yang optimal. Untuk mengoptimalkan motivasi guru maka dapat dilakukan dengan pemenuhan kebutuhan mempertahankan hidup, kebutuhan akan rasa aman, kebutuhan sosial, kebutuhan akan penghargaan, kebutuhan prestasi, kebutuhan dalam mengaktualisasikan diri di sekolah. Dengan demikian maka guru yang puas akan pekerjaannya akan mendorong guru termotivasi, sehingga meningkatkan kinerja guru.

\section{DAFTAR PUSTAKA}

Anderson, J. C., \& Gerbing. (1988). Structural equation modeling in practice: A Review and recommended two step approach. Psychological Bulletin, 103, 411-423

Anorogo, P. (2009). Manajemen bisnis. Jakarta: Rhineka Cipta

Anthony, R.N ., \& Govindarajan, V. (2001). Management control systems. New York: McGraw-Hill, Inc.

Armstrong, M.. (2004) Performance management. Yogyakarta: Tugu Publisher

As'ad, M. (2003). Psikologi industri (ed.4). Yogyakarta: Liberty.

Astiti. (2015). Pengaruh kepuasan kerja dan kepuasan kerja terhadap kinerja guru honorer. Tesis. Yogyakarta: Univesitas Negeri Yogyakarta.

Bestiana. (2012). Hubungan kepuasan kerja, motivasi dan komitmen normatif dengan kinerja guru SMPN 1 Rantau Selatan - Labuhan Batu. Jurnal Tabularasa PPS Unimed, 9 (2), 187- 200.

Chukwuma, E. M., \& Obiefuna, O. (2014). Effect of motivation on employee productivity : A study of manufacturing companies in Nnewi. Journal of Managerial Studies and Research 2, 7.

Dale, A. T. (1992). Seri ilmu dan seni manajemen bisnis kinerja. Jakarta: PT Gramedi.

Departemen Pendidikan Nasional. (2003). Undang-undang nomor 20 tahun 2003, tentang sistem pendidikan nasional. Jakarta: Depdiknas

Dessler. (1997). Kinerja. Jakarta: PT. Elek Media Komputindo, Gramedia.

Ghozali, I. (2011). Aplikasi analisis multi variate dengan program SPSS. Semarang: Badan Penerbit UNDIP. 
Jurnal Psikologi Terapan dan Pendidikan

ISSN: $2715-2456$

Vol. 1, No. 1, Mei 2019, pp. 30-44

Gibson, L. J., Ivancevich, J., Donnely, J. H. (2003). Organizations behavior, strukture, processes. New York: Mc Graw Hill.

Hasibuan, S. P. (2002). Organisasi dan motivasi. Jakarta: P T Bumi Aksara.

Ika. (2011). Pengaruh kepuasan kerja dan kompensasi terhadap kinerja guru honorer. Tesis. Yogyakarta: Pasca Sarjana Univesitas Negeri Yogyakarta.

Komaruddin. (1985). Media penelitian skripsi dan thesis. Bandung: Angkasa.

Luthans, F. (2005). Organization behavior (ed.8). New York: McGraw-Hill.

Miftahun., \& Sugiyanto. (2010). Pengaruh dukungan sosial dan kepemimpinan transformasional terhadap komitmen organisasi dengan mediator motivasi kerja. Jurnal psikologi 37(1), 94 - 109.

Munandar, S. C. U. (2003). Pengembangan krativitas anak berbakat. Jakarta: Gramedia Pustaka Utama

Munandar, A. S. (2001). Psikologi industri dan organisasi. Jakarta: UI-Press.

Mulyana Deddy, M.A., Ph.D. (2010). Metode penelitian kualitatif. Jakarta : Rosda.

Mulyasa. (2006). Kurikulum berbasis kompetensi (konsep, karakteristik, dan implementasi), Bandung: Remaja Rosdakarya.

Mulyasa. (2013). Pengembangan dan implentasi pemikiran kurikulum. Bandung: Rosdakarya

Pamela, A.O., \& Oloko. (2015). Effect of motivation on employee performance of commercial banks in kenya : A case study of Kenya Commercial Bank in Migori County. Journal of Human Resource Studies $5,2$.

Prabu Anwar \& Mangkunegara. (2005). Evalusi kinerja SDM. Bandung: Refika Aditama.

Pujiyanti \& Iroah. (2013). Pengaruh motivasi kerja dan disiplin kerja kerhadap kinerja guru SMA Negeri 1 Ciamis. Kajian Pendidikan Akuntansi Indonesia. 2 (1).

Puspitasari , Dewi \& Setia Asyanti. (2011). Faktor yang paling berpengaruh terhadap komitmen kerja perawat panti wreda di Surakarta. Jurnal Psikologi Undip , 9(1), 57-64.

Robbins, S. P. (1996). Perilaku organisasi: Konsep, kontroversi dan aplikasi. Jakarta: Pearson Education Asia Pte Ltd dan PT Prenhallindo.

Robbins Stephen P. 2001. Perilaku Organisasi: Konsep, kontroversi, aplikasi (ed.8). Jakarta: Prenhallindo.

Robert L. Mathis., \& John H. J. (2006). Human resource management. Jakarta: Selemba Empat.

Saraswati, M., \& Ida W. (2008). Be smart ilmu pengetahuan sosial. Jakarta: PT Grafindo Media Pertama

Sigit S. (2001). Pengantar metodologi penelitian. Yogyakarta: BPFE.

Sudjana. (2006). Metode statistik. Jakarta: Rineka Cipta

Susant Palupiningdyah. (2016). Pengaruh kepuasan kerja dan komitmen organisasi terhadap kinerja karyawan dengan turnover intention sebagai variabel intervening. Management Analysis Journal, 5 (1)

Wan F. W. Y., \& Tan, S. K. (2013). Generation Differences in work motivation : From developing country persepctive. Journal of Economy, Management and sosial Sciences, 2(4), 97-103.

Wakir. (2012). Pengaruh kompetensi dan motivasi terhadap kinerja guru SMA Muhammadiyah Se Kabupaten Bantul Tahun Pelajaran 2011/2012. Tesis. Yogyakarta: Pasca Sarjana Program Magister Manajemen Univesitas Muhammadiyah Yogyakarta. 
Jurnal Psikologi Terapan dan Pendidikan

ISSN: $2715-2456$

Vol. 1, No. 1, Mei 2019, pp. 30-44

Wirawan. (2009). Evaluasi kinerja sumber daya manusia teori aplikasi dan penelitian. Jakarta: Salemba Empat.

Yamin, Martinis \& Maisah, (2010). Standarisasi kinerja guru. Jakarta: GP Press.

Yohana, Corry. (2012). Pengaruh profesionalisme, kepuasan kerja dan komitmen organisasi terhadap kinerja guru di SMPN Pamulang Tanggerang Selatan. Jurnal ilmiah Econo Sains- X, 2. 